\title{
Post-transcriptional regulatory network of epithelial-to-mesenchymal and mesenchymal-to-epithelial transitions
}

Fei Guo ${ }^{1,5}$, Brittany C Parker Kerrigan ${ }^{1}$, Da Yang ${ }^{1}$, Limei Hu', llya Shmulevich ${ }^{6}$, Anil K Sood ${ }^{2,3,4}$, Fengxia Xue ${ }^{5 *}$ and Wei Zhang ${ }^{1 *}$

\begin{abstract}
Epithelial-to-mesenchymal transition (EMT) and its reverse process, mesenchymal-to-epithelial transition (MET), play important roles in embryogenesis, stem cell biology, and cancer progression. EMT can be regulated by many signaling pathways and regulatory transcriptional networks. Furthermore, post-transcriptional regulatory networks regulate EMT; these networks include the long non-coding RNA (IncRNA) and microRNA (miRNA) families. Specifically, the miR-200 family, miR-101, miR-506, and several IncRNAs have been found to regulate EMT. Recent studies have illustrated that several IncRNAs are overexpressed in various cancers and that they can promote tumor metastasis by inducing EMT. MiRNA controls EMT by regulating EMT transcription factors or other EMT regulators, suggesting that IncRNAs and miRNA are novel therapeutic targets for the treatment of cancer. Further efforts have shown that non-coding-mediated EMT regulation is closely associated with epigenetic regulation through promoter methylation (e.g., miR-200 or miR-506) and protein regulation (e.g., SET8 via miR-502). The formation of gene fusions has also been found to promote EMT in prostate cancer. In this review, we discuss the post-transcriptional regulatory network that is involved in EMT and MET and how targeting EMT and MET may provide effective therapeutics for human disease.
\end{abstract}

Keywords: Long non-coding RNA (IncRNA), microRNA (miRNA), Epithelial-to-mesenchymal transition (EMT), Mesenchymal-to-epithelial transition (MET)

\section{Introduction}

EMT is a process whereby epithelial cells lose both polarity and cell-to-cell contacts. Cells undergoing EMT acquire a mesenchymal phenotype, which is characterized by an epithelial-to-mesenchymal switch in marker expression, such as the loss of epithelial markers (e.g., E-cadherin, claudin, and occludin) and gain of mesenchymal markers (e.g., vimentin and $\mathrm{N}$-cadherin). The reverse process, known as mesenchymal-to-epithelial transition (MET), has also been reported [1]. EMT and MET are important in organ development, stem cell biology, wound healing, and cancer progression. Many signals, transcriptional factors, and post-transcriptional regulatory networks can

\footnotetext{
* Correspondence: fengxiaxue1962@163.com; wzhang@mdanderson.org ${ }^{5}$ Department of Gynecology and Obstetrics, Tianjin Medical University General Hospital, No. 154, Anshan Rd, Heping District, Tianjin 300052, People's Republic of China

'Department of Pathology, Unit 85, The University of Texas MD Anderson Cancer Center, 1515 Holcombe Blvd, Houston, TX 77030, USA

Full list of author information is available at the end of the article
}

induce EMT. Post-transcriptional regulatory networks include the miRNA and lncRNA families. Therefore, in this review, we focus on miRNA and lncRNA, which may be effective diagnostic and therapeutic targets in cancer. Specifically, we describe several lncRNAs that regulate EMT in cancer, as well as miRNAs that regulate multiple signaling pathways involved in EMT and transcription factors of E-cadherin.

\section{EMT and MET regulate important processes, including disease}

EMT and MET have central roles in embryogenesis and cancer metastasis [2]. EMT is an integral part of tissue remodeling that occurs during embryogenesis [1]. MET also contributes to embryonic development [3]. In adults, EMT can be activated to promote wound healing after tissue injury [4]. EMT induction allows cancer cells to disseminate from the primary tumor, invade surrounding tissues, and eventually generate metastases by colonizing 
remote sites via blood or lymphatic routes. Metastatic cells can then revert back via MET to re-acquire epithelial characteristics similar to those of cells in the primary tumor [4].

EMT and MET are essential to the regulation of stem cell pluripotency [4]. Tumors contain cancer stem cells (CSCs), which are a small subpopulation of cells that are capable of self-renewal, differentiation, and tumorigenicity. Evidence suggests that EMT induction enhances self-renewal and the acquisition of CSC characteristics [5]. Thus, therapeutics that target EMT may be useful for reducing $\mathrm{CSC}$ populations in cancer.

\section{Key regulators involved in EMT and MET}

During EMT, epithelial cells lose cell-to-cell interactions, undergo morphological challenges, and increase their cellular motility. The most important mediator of cell-tocell adhesion is the cadherin family of proteins, which promotes the formation of adherens junctions that act as glue to hold the cells within tissues together. The most characterized cadherins include E-, N-, and P-cadherin. E-cadherin plays an important role in epithelial cell-tocell interactions because it is responsible for holding neighboring epithelial cells together in a classic cobblestone structure. During EMT, E-cadherin is replaced by abnormal expression of $\mathrm{N}$ - or P-cadherin. The downregulation of E-cadherin leads to the release of $\beta$-catenin, and the latter translocates to the nucleus and functions as an activator for transcription factors, promoting cellular adhesion, tissue morphogenesis, and cancer development.

Other proteins that mediate EMT include vimentin and fibronectin. Vimentin is an intermediate filament protein that is upregulated in cells undergoing EMT. During EMT, vimentin expression causes epithelial cells to acquire a mesenchymal shape and increased motility [6]. Fibronectin mediates cellular interactions with the extracellular matrix and is important for migration, differentiation, growth, and cell adhesion. Like vimentin, fibronectin is also upregulated during EMT and can therefore be used as a biomarker for EMT (Figure 1).

EMT is regulated by many signaling pathways, transcriptional factors, and post-transcriptional factors. Many signals, including transforming growth factor- $\beta$ (TGF- $\beta$ ), fibroblast growth factor (FGF), human growth factor (HGF), platelet-derived growth factor (PDGF), insulin-like growth factor (IGF) (and its receptor [IGFR]), vascular endothelial growth factor (VEGF), estrogen receptor (ER $\alpha$ ), Notch, Wnt, and epidermal growth factor (EGF) may be involved in EMT. These pathways ultimately activate the transcription of EMT-related transcription factor families, including ZEB (ZEB1 and ZEB2), the zinc finger Snail (SNAI1 and SNAI2), and the basic helix-loop-helix (e.g., Twist1 and Twist2) [7]. By regulating the expression of E-cadherin, these transcription factors

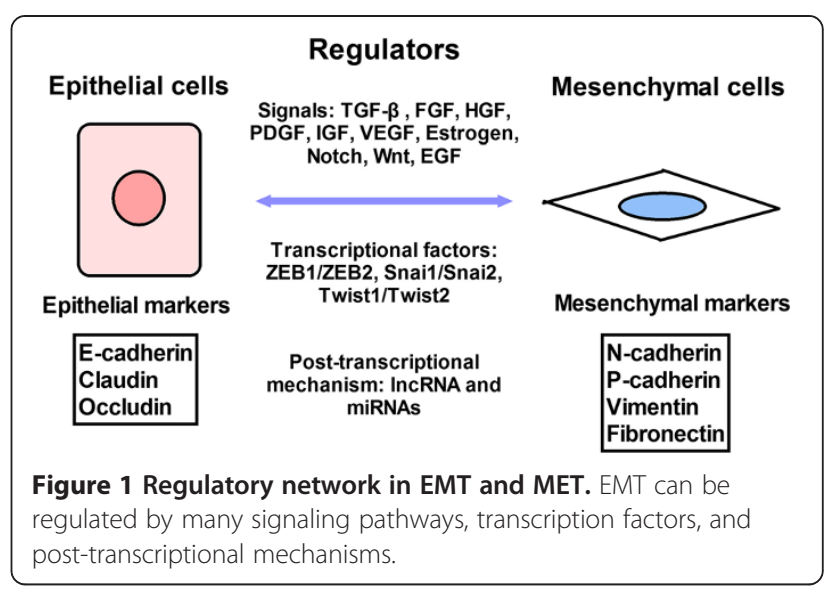

dynamically modulate EMT, cell adhesion, and motility. In addition to transcription factors, EMT is regulated by post-transcriptional mechanisms, including lncRNA and miRNA (Figure 1).

\section{Regulation of EMT by IncRNAs}

LncRNA, which is larger than $200 \mathrm{nt}$, consists of a heterogeneous group of RNA molecules that are involved in a broad spectrum of cellular processes and in cancer progression [8]. Studies have demonstrated that lncRNAs are aberrantly expressed in a variety of human cancers, such as gastric cancer $[9,10]$, bladder cancer $[11,12]$, and breast cancer [13]. Interestingly, a recent report revealed that several lncRNAs may be involved in EMT regulation [14].

Several important lncRNAs are reported to induce EMT, including highly upregulated in liver cancer (HULC), metastasis-associated lung adenocarcinoma transcript 1 (MALAT-1), H19, and HOX transcript antisense intergenic RNA (HOTAIR).

HULC overexpression in gastric cancer was found to be correlated with lymph node metastasis, distant metastasis, and advanced tumor node metastasis stage [9]. Silencing of HULC effectively reversed the EMT phenotype [9]. MALAT-1 expression was remarkably increased in primary tumors that subsequently metastasized compared with those that did not metastasize. MALAT-1 promoted EMT by activating Wnt signaling in vitro [11]. H19 enhanced bladder cancer metastasis by associating with EZH2 and inhibiting E-cadherin expression [12].

The expression level of HOTAIR was significantly correlated with lymph node metastasis and TNM stage in gastric cancer. The results of in vitro studies suggested that HOTAIR promoted EMT by regulating Snail [10]. HOTAIR remodels the gene expression pattern of breast epithelial cells into a pattern that more closely resembles that of embryonic fibroblasts, leading to increased cancer invasiveness and metastasis [13]. HOTAIR resides in the mammalian HOXC locus and recruits the polycomb repressive complex 2 to specific target genes genome 
wide, leading to histone $\mathrm{H} 3$ lysine 27 trimethylation and epigenetic silencing of metastasis-suppressor genes.

The findings described above indicate that IncRNA has a role in tumor diagnosis and therapy. Recently, the therapeutic potential of targeting MALAT-1 was demonstrated, as free uptake of antisense oligonucleotides that target MALAT-1 in tumors prevented lung metastasis in nude mice [15]. Together, these results suggest that therapy is needed that hinders cancer progression by targeting specific lncRNAs that are implicated in EMT and therefore metastasis.

\section{Regulation of EMT by miRNA}

A second post-transcriptional mechanism that contributes to EMT involves miRNAs, which are 22-nucleotide non-coding RNAs that suppress gene expression through mRNA destabilization or translational inhibition. They are deregulated in a wide variety of human cancers [16] and have been shown to contribute to the control of cell growth, differentiation, and apoptosis, which are important to cancer development and progression [17]. MiRNAs can regulate multiple signaling pathways involved in EMT. Specifically, they can directly target transcription factors of E-cadherin and other EMT regulators.

\section{MiRNAs regulate signaling pathways involved in EMT}

Many miRNAs influence the EMT process by targeting the expression of specific ligands, receptors, and signaling pathways (Figure 2). Increasing evidence indicates that miRNAs regulate EMT by targeting key EMT regulators, including FGF (and its receptor [FGFR]), HGF, IGF (and IGFR), ER $\alpha$, Notch, and Wnt. MiR-15 and miR-16 were downregulated in cancer-associated fibroblasts (CAFs) surrounding prostate tumors. This downregulation promoted tumor growth and progression through reduced post-transcriptional repression of FGF-2 and its receptor FGFR1, which act on both stromal and tumor cells to enhance cancer cell survival, proliferation, and migration [18]. Emerging evidence indicates that miR-198 is downregulated in hepatocellular carcinoma compared with in normal liver parenchyma, and forced expression of miR198 inhibited HGF's promotion of hepatocellular carcinoma cell migration and invasion in a c-MET-dependent manner [19]. A recent report showed that miR-7 suppresses Snail, increases E-cadherin expression, and partially reverses EMT by targeting IGF1R, generating a novel miR-7/IGF1R/Snail axis in gastric cancer [20]. As we know, ER $\alpha$ signaling opposes EMT by inhibiting TGF$\beta$ and cytokine signaling through Smad and nuclear factor- $\mathrm{kB}$. Another report demonstrated that miR-206,

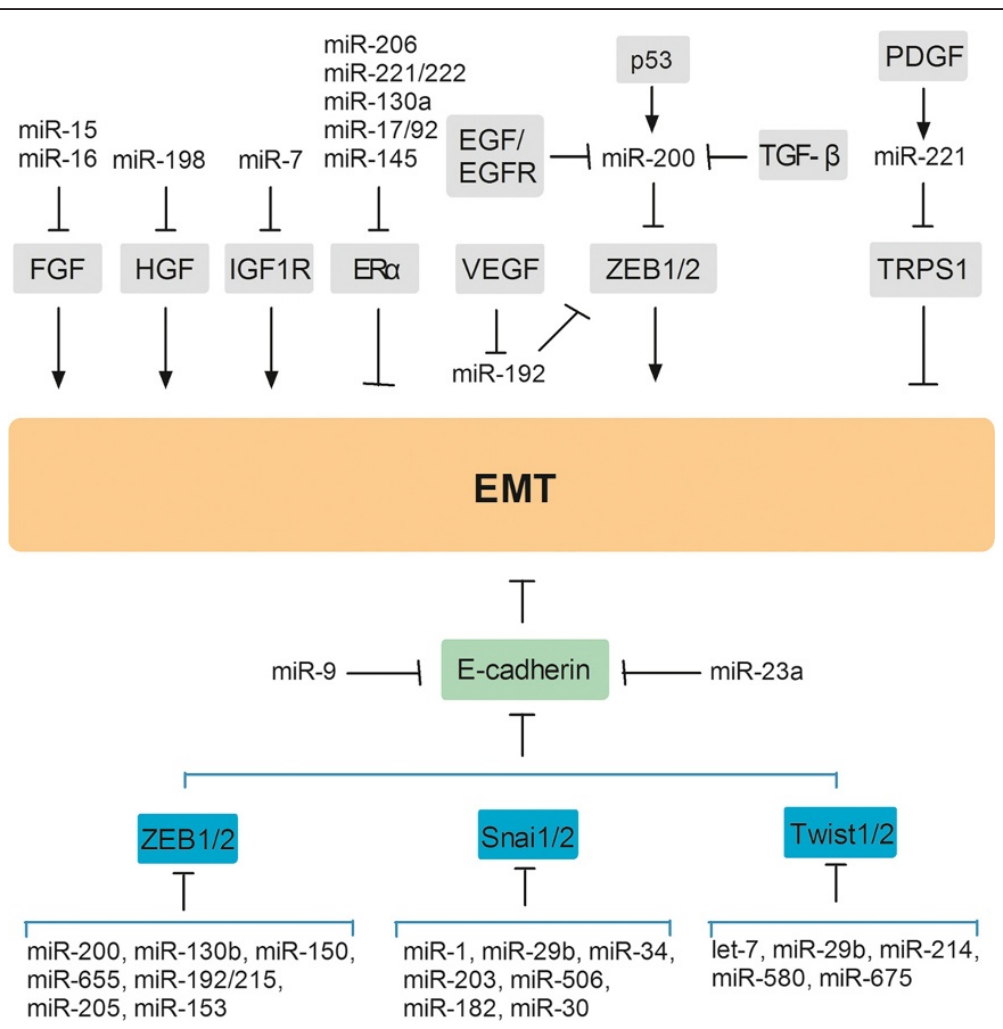

Figure 2 MiRNA-regulating signaling pathways and transcription factors are involved in EMT. MiRNA influences EMT by targeting ligands, receptors, signaling pathways and transcription factors. 
miR-221, miR-222, miR-130a, miR-17, miR-92, and miR145 could suppress ER $\alpha$ and promote EMT [21]. MiR-34a can regulate EMT by directly targeting Notch 1 and Jagged1 [22]. Furthermore, a recent study illustrated that miR-200 members can target Jagged1, thereby mediating the downregulation of ZEB1 [23]. The Wnt/ß-catenin signal pathway promotes EMT in cancer, and miR-200a was found to inhibit Wnt/ $\beta$-catenin by targeting ZEB1 and ZEB2. MiR-200 can directly target $\beta$-catenin mRNA, inhibiting its translation and blocking Wnt/ $\beta$-catenin signaling in meningioma [24].

MiRNA can also regulate EMT by targeting signaling pathways, including the TGF- $\beta$, PDGF, VEGF, and EGF pathways. TGF- $\beta$ is a well-known EMT initiator. Exposing epithelial cells to TGF- $\beta$ promotes the loss of epithelial morphological features, the increased expression of EMT marker genes such as ZEB1 and ZEB2, and the decreased expression of miR-200 [25]. Furthermore, downregulating paracrine TGF- $\beta$ can inhibit and reverse EMT by downregulating ZEB1 and ZEB2 and upregulating miR-200b and miR-200c [26]. Inhibition of the Smad signaling pathway completely blocked the TGF- $\beta 1$ mediated decrease in miR-200, suggesting that TGF- $\beta 1$ induced suppression of the miR-200 family is regulated via Smad [27]. In addition, miR-99a and miR-99b may function as modulators within a complex network of factors that regulate TGF- $\beta$-induced EMT [28].

Anping $\mathrm{Su}$ et al. demonstrated that downregulation of TRPS1 by miR-221 is critical for the PDGF-mediated EMT phenotype [29]. VEGF was reported to suppress EMT by inhibiting the expression of miR-192 [30], which increases E-cadherin levels via repressed translation of ZEB2 mRNA [31]. Similarly, it was reported that EGF and EGFR can promote EMT by downregulating the miR-200 family in anaplastic thyroid cancer cells [32]. Furthermore, miR-155 overexpression suppressed EGF-induced EMT, decreased migration and invasion, inhibited cell proliferation, and increased chemosensitivity to DDP in human Caski cervical cancer cells [33]. Together, these data underscore the importance of miRNAs in EMT and malignant tumor progression.

\section{MiRNAs that regulate E-cadherin transcription factors ZEB1 and ZEB2}

The expression of E-cadherin is mainly controlled by three families of transcription factors: SNAI1 and SNAI2, ZEB1 and ZEB2, and Twist1 and Twist2. Several miRNAs directly target these families to modulate EMT in cancer (Figure 2). Members of the miR-200 family (miR-200a, miR-200b, miR-200c, miR-141, and miR-429) have emerged as important regulators of EMT, in part by targeting ZEB1 and ZEB2. Moreover, some signaling pathways, including p53, regulate EMT by regulating the miR-200ZEB1 and ZEB2 regulatory loop.
The miR-200 family is usually downregulated in human cancer cells and tumors as a result of aberrant epigenetic gene silencing. The results of recent studies suggest that members of the miR-200 family play a critical role in suppressing EMT and cancer invasion and metastasis [34] by targeting transcriptional repressors of ZEB1 and ZEB2 [35]. Meanwhile, ZEB1 can directly suppress miRNA-200 family members in cancer cells, including miR-141 and miR-200c [36,37]. It was also reported that ZEB1 and ZEB2 repressed the expression of miR-200a, miR-200b, and miR-429 by binding to a conserved pair of ZEB-type E-box elements located proximal to the transcription start site in the promoter region [38]. Therefore, ZEB1 and ZEB2 and miR-200 family members repress expression of each other in a reciprocal feedback loop, which may lead to amplification of EMT. Targeting this loop may be a new therapeutic strategy for cancer.

\section{Pathways that suppress EMT by upregulating miR-200 and repressing ZEB1 and ZEB2}

Several molecules have been found to upregulate the miR-200 family and consequently suppress EMT. For example, both P300 and PCAF act as cofactors for ZEB1, forming a P300/PCAF/ZEB1 complex on the miR200c/ 141 promoter. This results in lysine acetylation of ZEB1 and releases ZEB1's suppression of miR-200c/141 transcription [39]. Smad3 was also reported to upregulate miR-200 family members at the transcriptional level in a TGF- $\beta$-independent manner [40]. p53 has been reported to transactivate miR-200 family members by directly binding to the promoters that repress ZEB1 and ZEB2 expression, leading to inhibition of EMT $[41,42]$. Similarly, NPV-LDE-225 suppressed EMT by upregulating E-cadherin and inhibited N-cadherin, Snail, Slug, and ZEB1 by increasing miR-200a, miR-200b, and miR-200c [43].

\section{Pathways that promote EMT by suppressing miR-200 and upregulating ZEB1 and ZEB2}

In addition to their role in regulating EMT, miR-200 family members are negatively regulated by multiple signaling pathways. For example, in one study, overexpression of Stat3 [44], PDGF-D [45], Notch-1 [46], and DCLK1 [47] in cancer cells led to significant downregulation of miR-200 family members; this resulted in upregulation of ZEB1, ZEB2, and SNAI2 expression and acquisition of the EMT phenotype. IDH1 and IDH2 mutants also caused an EMT-like phenotype; this phenotype was dependent on upregulation of the transcription factor ZEB1 and downregulation of miR-200 family members [48]. Other miRNAs can induce EMT by downregulating miR-200 through DICER, such as miR-103 or miR-107 [49]. Similarly, miR-130b silencing can restore DICER1 to a threshold level that allows miR-200 family members to repress EMT in endometrial cancer [50]. All of these 
findings indicate that these molecules promote EMT by suppressing miR-200.

Fusion genes are formed when chromosomal instability causes two genes that normally exist in isolation to fuse together [51]. Interestingly, a well-known gene fusion in prostate cancer that is produced by deletion of a 3-mega base region between ERG and TMPRSS2 [52] (also reviewed in [Parker 2014 Journal of Pathology]) has also been found to upregulate ZEB1 and ZEB2 expression [53]. Specifically, expression of the TMPRSS2-ERG fusion gene caused epithelial immortalized prostate epithelial cells to undergo morphological changes consistent with those of mesenchymal cells while downregulating expression of the epithelial marker $C D H 1$ [53]. This finding highlights the complex ways in which EMT can be facilitated at the genetic level, simply by the fusion of two genes.

\section{Epigenetic regulation of miR-200}

MiR-200 family members can also be epigenetically regulated. It was reported that miR-200c expression was epigenetically regulated in CRC [54]. Rui Neves et al. also showed that the miR-200c/141 cluster is repressed by DNA methylation of a CpG island located in the promoter region of these miRNAs in invasive breast cancer cells [55].

The miR-200 family consists of five members in two clusters: miR-200b $\sim 200 \mathrm{a} \sim 429$ and miR-200c $\sim 141$. Studies have illustrated DNA methylation in two regions (\#1 and \#2) of a 2.5-kb large CpG island that is $2 \mathrm{~kb}$ upstream in miR-200b 429 and in smaller CpG-enriched regions associated with miR-200c $\sim 141$. These regions can be demethylated by 5-Aza-20-deoxycytidine and the histone deacetylase inhibitor trichostatin A [56]. Aberrant DNA methylation of the CpG island or the CpG-enriched regions is closely linked to miR-200 inappropriate silencing in cancer cells [57]. Other factors may also be involved in miR-200 repression, such as ZEB1 and Twist1. A recent study showed that induction of ZEB1 and ZEB2 increased the methylation of miR-200 promoters [58]. Twist1 was also reported to directly associate with miR200 promoters as a transcriptional repressor of miR-200 [56] (Figure 3A).

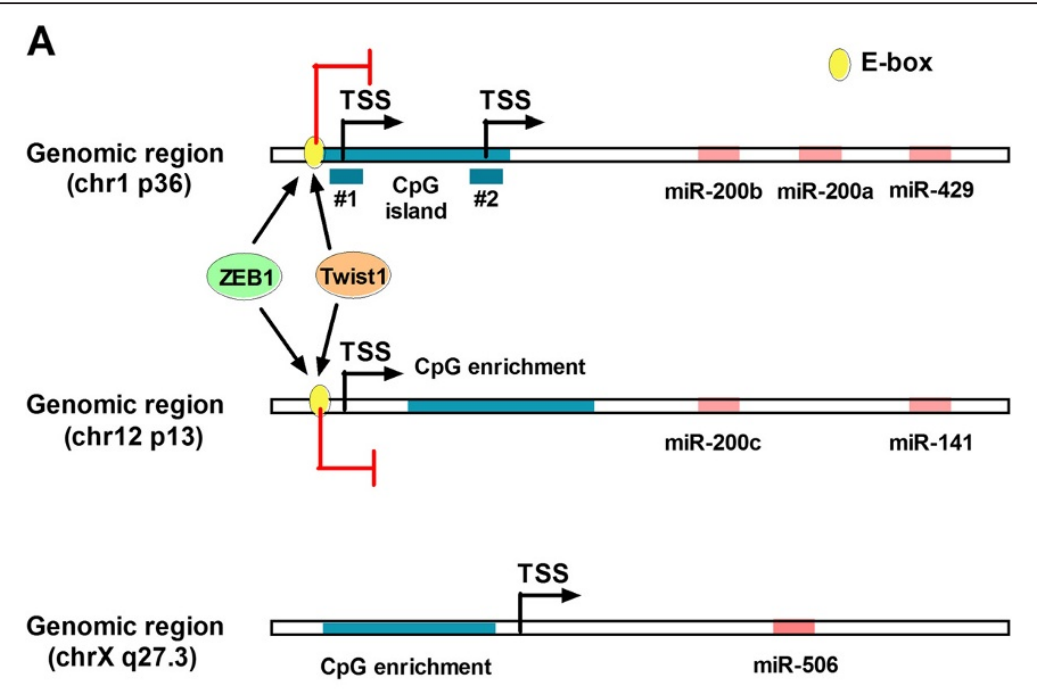

B

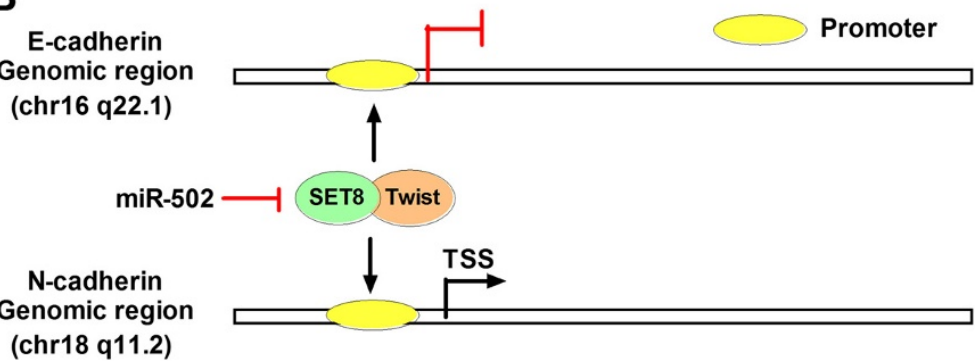

Figure 3 MiR-200 and miR-506 DNA methylation genomic loci and promoters of E- and N-cadherin. A. Graphical depiction of the miR-200b $\sim 429$ and miR-200c 141 genomic loci, with putative transcription start sites (TSS) indicated by arrows. ZEB1 and Twist1 bound the E-box consensus in the promoters proximal to the putative miR-200 TSS and repressed miR-200 expression. The genomic position of miR-506 and five candidate methylation-regulated positions are also shown. B. SET8 interacted with Twist to regulate E-cadherin or $\mathrm{N}$-cadherin promoter. MiR-502 suppressed SET8 directly and promoted E-cadherin expression. 


\section{MiRNAs other than miR-200 inhibit EMT by targeting ZEB1 and ZEB2}

In addition to miR-200 family members, other miRNAs have been identified that regulate EMT by directly targeting ZEB1 and ZEB2. For example, miR-130b [59], miR-150 [60], and miR-655 [61] inhibit EMT by directly targeting ZEB1. Ectopic expression of miR-192 and miR215 increased E-cadherin levels by targeting ZEB2 [31]. MiR-205, which is induced by p63, was reported to inhibit EMT by targeting ZEB1 and ZEB2 [35] in breast cancer [62] and prostate cancer [63]. MiR-153 is a novel regulator of EMT that targets ZEB2 and SNAI1 [64].

\section{MiRNAs that regulate SNAI1 and SNAI2}

MiR-34 inhibits EMT by directly targeting SNAI1 [65]. Moreover, SNAI1 can repress transcription of miR-34 genes, resulting in a SNAI1/miR-34 feedback loop that is analogous to the reciprocal $\mathrm{ZEB} / \mathrm{miR}-200$ feedback loop [66]. MiR-34 targets a set of highly conserved sites in the 3' untranslated region (UTR) of Wnt and EMT genes, specifically WNT1, WNT3, LRP6, AXIN2, $\beta$-catenin, and $L E F 1$, resulting in suppression of TCF/LEF transcriptional activity and the EMT process [67].

MiR-203 was found to be repressed by SNAI1 during SNAI1-induced EMT in MCF7 breast cancer cells. Meanwhile, miR-203 repressed endogenous SNAI1, forming a double-negative miR203/SNAI1 feedback loop [68]. miR203 targeted SNAI2 [69], and SNAI2 directly bound to the miR-203 promoter to inhibit its transcription. Therefore, miR-203 also formed a double-negative feedback loop with SNAI2 in which each inhibited the other's expression, thereby controlling EMT [70]. In another double-feedback loop, miR-200 and SNAI2 regulate EMT. While SNAI2 is targeted by miR-200, SNAI2 directly binds E-boxes in the miR-200a/b promoter regions and represses miR-200a/b transcription. Therefore, SNAI2 and miR-200 act in a self-reinforcing regulatory loop that leads to amplification of EMT [71].

The results of a recent report suggest that miR-506 is a novel microRNA that inhibits EMT [72]. Integrated genomic analyses revealed a miRNA-regulatory network that is involved in EMT in serous ovarian cancer (Figure 4). MiR-506 augmented E-cadherin expression, inhibited cell migration and invasion, and prevented TGF $\beta$-induced EMT by targeting SNAI2. MiR-506 expression is downregulated in an integrated mesenchymal subtype of serous ovarian cancer through methylation of $\mathrm{CpG}$ sites on the miR-506 promoter (Figure 3A). The nanoparticle delivery of miR-506 in orthotopic ovarian cancer mouse models led to E-cadherin induction and reduced tumor growth [72].

Several other miRNAs also target SNAI1 and SNAI2, such as miR-182 [69], miR-30 [73], miR-1 [71], and miR-29b [74] (Figure 2).

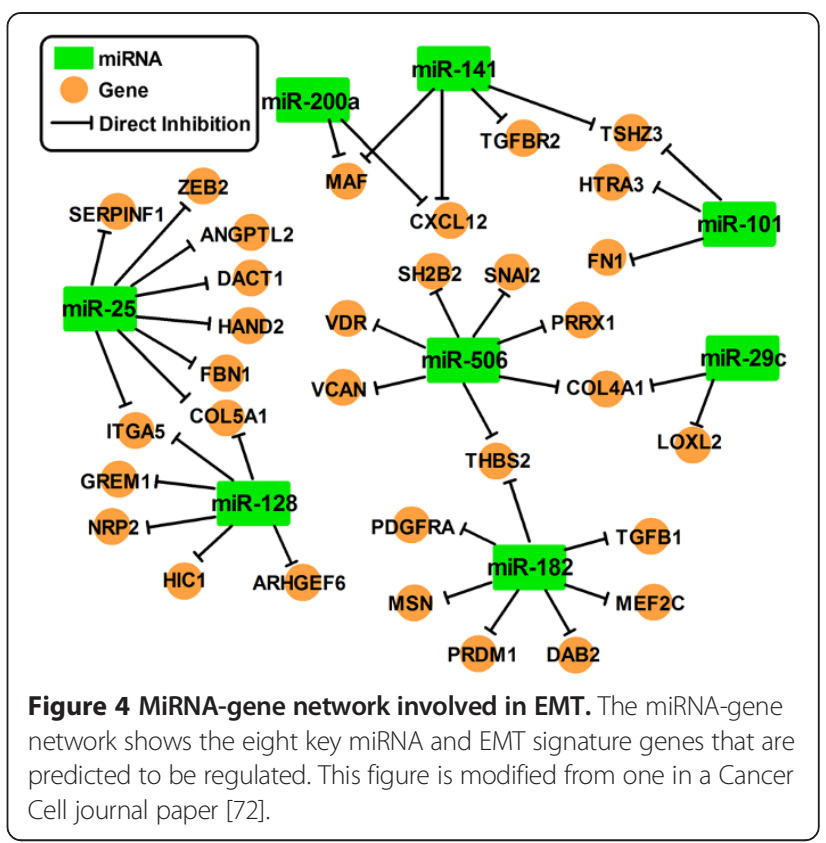

MiRNAs that regulate Twist1 and Twist2

The transcription factor Twist is a highly conserved basic helix-loop-helix transcription factor that promotes EMT and tumor metastasis. Apart from let-7d [75], miR29b [74], and miR-214 [76], miR-580 was also reported to act as a negative regulator of Twist1 that induces EMT in breast cancer [77]. MiR-675 similarly directly downregulates Twist1 expression, leading to EMT [78] (Figure 2).

The results of a recent study showed that SET8 promotes EMT and enhances the invasive potential of breast cancer cells in vitro and in vivo by interacting with Twist. SET8 interacts with Twist to regulate the E-cadherin or $\mathrm{N}$-cadherin promoter [79]. Fengju Song et al. identified a single-nucleotide polymorphism within the miR-502 seedbinding region in the 3'-UTR of the SET8 genethat modulates SET8 expression [80]. Thus, miR-502 may suppress EMT by inhibiting SET8 (Figure 3B).

\section{MiRNAs directly regulate E-cadherin}

Both miR-9 [81] and miR-23a [82] directly target Ecadherin, leading to increased cell motility and invasiveness (Figure 2). As miR-9 can be regulated by c-Myc and Prospero homeobox 1 , overexpression of both $[83,84]$ led to EMT; it also resulted in a significant decrease in E-cadherin and increase in vimentin through the upregulation of miR-9. In addition, miR-9 promoted EMT and metastasis by directly regulating KLF17 expression [85].

\section{MiRNAs regulate vimentin and fibronectin}

MiR-506 was reported to inhibit TGF $\beta$-induced EMT by directly targeting vimentin in a human breast cancer cell line [86]. MiR-30 was reported to suppress the migratory 
ability and invasiveness of breast cancer cell lines by directly targeting vimentin [87]. Furthermore, MiR-17-3p [88], as well as miR-124 and miR-203 [89], repressed vimentin expression by targeting its 3 'UTR. miR-138 suppressed cell migration and invasion by directly targeting vimentin in renal cell carcinoma [90] and squamous cell carcinoma cells [91].

The results of another report suggested that miRNA200b suppresses TGF- $\beta 1$-induced EMT by directly targeting the 3'UTR of fibronectin [92]. Similarly, miR-17 resulted in decreased cell adhesion and migration by directly targeting fibronectin [93].

Since miRNAs play important roles in EMT and cancer metastasis, there is growing interest in using them in therapeutic applications [94]. Downregulation of the miRNAs that promote cancer progression may provide effective therapeutics for patients by using specific oligomers, called antagomirs that compete with the target mRNA to bind to miRNA. Krutzfeldt et al. found that antagomirs are powerful tools to silence specific miRNA in vivo and may represent a therapeutic strategy for silencing miRNAs in disease [95]. Meanwhile, the restoration of tumor-suppressive miRNA in tumors by external delivery may serve as a promising therapeutic option [96]. A report suggested that miR-200b and miR-200c were significantly associated with survival in gastric cancer patients; miR-200b suppressed ZEB1, augmented E-cadherin, inhibited cell migration, and suppressed tumor growth in a mouse model [97]. Furthermore, delivery of miR-200 members into the tumor endothelium resulted in marked reductions in metastasis and angiogenesis [98].

\section{Conclusions and future directions}

A plethora of miRNAs, including miR-200 family members and miR-506, have been found to directly regulate the expression of the target genes that are known to play critical roles in EMT regulation (Figure 4). As shown in Table 1, aside from regulating the signaling pathways and transcriptional factors described above, miRNAs regulate other genes to modulate EMT in various cancer types.

Targeting EMT and MET may provide effective therapeutics for cancer. However, therapeutic intervention may be complex because EMT occurs at an early stage of metastasis and MET occurs at later stages. MiRNAs that inhibit EMT, such as miR-141, were found in the circulation of patients with metastatic colon cancer, and high levels of plasma miR-141 were predictive of poor survival [122]. As miR-141 may promote MET, it is conceivable that miR-141 promotes tumor growth at distant sites at a late stage of metastasis, a theory that warrants further investigation. A recent report by Oscar et al. provided supporting evidence that MET is essential for
Table 1 MiRNAs that regulate EMT and their targets in different cancer types

\begin{tabular}{|c|c|c|c|}
\hline Cancer type & miRNA & Target & Reference \\
\hline \multirow[t]{9}{*}{ Breast } & miR-24 & Net1A & [99] \\
\hline & miR-29a & TTP & {$[100]$} \\
\hline & miR-106b-25 & SMAD7 & [101] \\
\hline & miR-221/222 & TRPS1 & {$[102]$} \\
\hline & miR-374a & WIF1, PTEN, WNT5A & [103] \\
\hline & miR-375 & $\mathrm{MTDH}$ & [104] \\
\hline & miR-448 & SATB1 & {$[105]$} \\
\hline & miR-506 & Vimentin, SNAI2, CD151 & {$[86]$} \\
\hline & miR-661 & Nectin-1, StarD10 & {$[106]$} \\
\hline \multirow[t]{4}{*}{ GC } & miR-7 & IGF1R & {$[20]$} \\
\hline & $\operatorname{miR}-27$ & APC & [107] \\
\hline & miR-106b-25 & SMAD7 & [101] \\
\hline & miR-197 & p120 catenin & [108] \\
\hline \multirow[t]{5}{*}{$\mathrm{HCC}$} & miR-21 & PTEN, hSulf-1 & [109] \\
\hline & miR-194 & BMl-1 & [110] \\
\hline & $\operatorname{miR}-490-3 p$ & ERGIC3 & [111] \\
\hline & miR-491 & MMP-9 & {$[112]$} \\
\hline & miR-612 & AKT2 & [113] \\
\hline HNSCC & miR-138 & Vimentin, ZEB2, EZH2 & [91] \\
\hline LAD & Let-7c & $\mathrm{BCl}-\mathrm{xl}$ & [114] \\
\hline Liver & miR-216a/217 & PTEN, SMAD7 & {$[115]$} \\
\hline Lung & miR-365 & HMGA2 & {$[116]$} \\
\hline Melanoma & miR-137 & CtBP1 & [117] \\
\hline \multirow[t]{2}{*}{ NSCLC } & miR-134 & FOXM1 & [118] \\
\hline & miR-149 & FOXM1 & [119] \\
\hline Ovarian & miR-187 & Dab2 & [120] \\
\hline Pancreatic & miR-126 & ADAM9 & [121] \\
\hline
\end{tabular}

Abbreviations: Net1A Neuroepithelial cell transforming 1, TTP Tristetraprolin, TRPS1 Trichorh inophalangeal 1, WIF1 Wnt inhibitory factor-1, MTDH Metadherin SATB1 Special AT-rich sequence-binding protein-1, GC Gastric cancer, IGF1R Insulin-like growth factor-1 receptor, APC Adenomatous polyposis coli, HCC Hepatocellular carcinoma, hSulf-1 Human sulfatase-1, BMI-1, B lymphoma mouse Moloney leukemia virus insertion region 1, ERGIC3 Endoplasmic reticulum-Golgi intermediate compartment protein $3, H N S C C$ Head and neck squamous cell carcinoma, LAD Lung adenocarcinoma, CtBP1 Carboxyl-terminal binding protein 1 , NSCLC Non-small cell lung cancer, FOXM1 Forkhead box M1, Dab2 Disabled homolog-2, ADAM9 Disintegrin and metalloproteinase domain-containing protein 9.

the colonization and metastasis of differentiated carcinomas because of EMT-associated growth arrest [123]. Jeff et al. also demonstrated that activation of EMT promotes local tumor invasion, intravasation, and extravasation of the systemic circulation; MET is essential for establishing macrometastases [124]. As EMT is associated with decreased cell proliferation and MET promotes metastatic growth, it is still unknown whether EMT inhibition is a logical approach to preventing metastasis. 
Most studies have shown that, as post-transcriptional regulators, lncRNA and miRNA play important roles in EMT and are important markers and tools in cancer diagnosis, prognosis, and therapeutics. However, lncRNA and miRNA have multiple targets that are involved in multiple different physiological processes; therefore, the role of therapeutics that target lncRNA or miRNA should be validated in vivo to determine their overall physiological effect.

\section{Competing interests}

The authors declare that they have no competing interests.

\section{Authors' contributions}

All authors contributed to discussing and writing this manuscript. All authors have read and approved the final manuscript.

\section{Acknowledgements}

We thank Ms. Ann Sutton in the Department of Scientific Publications at MD Anderson for editing this manuscript. This study was partially supported by U.S. National Institutes of Health grants U24 CA143835, P50 CA083639, and U54 CA151668; MD Anderson support grant CA016672; and a grant from the Blanton-Davis Ovarian Cancer Research Program.

\section{Author details}

${ }^{1}$ Department of Pathology, Unit 85, The University of Texas MD Anderson Cancer Center, 1515 Holcombe Blvd, Houston, TX 77030, USA. ${ }^{2}$ Gynecologic Oncology and Reproductive Medicine, The University of Texas MD Anderson Cancer Center, 1515 Holcombe Blvd, Houston, TX 77030, USA. ${ }^{3}$ Cancer Biology, The University of Texas MD Anderson Cancer Center, 1515 Holcombe Blvd, Houston, TX 77030, USA. ${ }^{4}$ Center for RNAi and Non-Coding RNA, The University of Texas MD Anderson Cancer Center, Houston, Texas, USA. ${ }^{5}$ Department of Gynecology and Obstetrics, Tianjin Medical University General Hospital, No. 154, Anshan Rd, Heping District, Tianjin 300052, People's Republic of China. ${ }^{6}$ Institute for Systems Biology, Seattle, Washington, USA.

Received: 13 January 2014 Accepted: 27 February 2014 Published: 5 March 2014

\section{References}

1. Thiery JP, Sleeman JP: Complex networks orchestrate epithelial-mesenchymal transitions. Nat Rev Mol Cell Biol 2006, 7:131-142.

2. Chang CC, Hsu WH, Wang CC, Chou CH, Kuo MY, Lin BR, Chen ST, Tai SK, Kuo ML, Yang $\mathrm{MH}$ : Connective tissue growth factor activates pluripotency genes and mesenchymal-epithelial transition in head and neck cancer cells. Cancer Res 2013, 73:4147-4157.

3. Wu CY, Tsai YP, Wu MZ, Teng SC, Wu KJ: Epigenetic reprogramming and post-transcriptional regulation during the epithelial-mesenchymal transition. Trends Genet 2012, 28:454-463.

4. Lamouille S, Subramanyam D, Blelloch R, Derynck R: Regulation of epithelial-mesenchymal and mesenchymal-epithelial transitions by microRNAs. Curr Opin Cell Biol 2013, 25:200-207.

5. Yu Z, Pestell TG, Lisanti MP, Pestell RG: Cancer stem cells. Int J Biochem Cell Biol 2012, 44:2144-2151.

6. Mendez MG, Kojima S, Goldman RD: Vimentin induces changes in cell shape, motility, and adhesion during the epithelial to mesenchymal transition. FASEB J 2010, 2010:24

7. Yang J, Eddy JA, Pan Y, Hategan A, Tabus I, Wang Y, Cogdell D, Price ND Pollock RE, Lazar AJ, Hunt KK, Trent JC, Zhang W: Integrated proteomics and genomics analysis reveals a novel mesenchymal to epithelial reverting transition in leiomyosarcoma through regulation of slug. Mol Cell Proteomics 2010, 9:2405-2413.

8. Huang T, Alvarez A, Hu B, Cheng SY: Noncoding RNAs in cancer and cancer stem cells. Chin J Cancer 2013, 32:582-593.

9. Zhao Y, Guo Q, Chen J, Hu J, Wang S, Sun Y: Role of long non-coding RNA HULC in cell proliferation, apoptosis and tumor metastasis of gastric cancer: a clinical and in vitro investigation. Oncol Rep 2014, 31:358-364.
10. $X u Z Y, Y u$ QM, Du YA, Yang LT, Dong RZ, Huang L, Yu PF, Cheng XD: Knockdown of long non-coding RNA HOTAIR suppresses tumor invasion and reverses epithelial-mesenchymal transition in gastric cancer. Int $J$ Biol Sci 2013, 9:587-597.

11. Ying $L$, Chen Q, Wang Y, Zhou Z, Huang Y, Qiu F: Upregulated MALAT-1 contributes to bladder cancer cell migration by inducing epithelial-tomesenchymal transition. Mol Biosyst 2012, 8:2289-2294.

12. Luo M, Li Z, Wang W, Zeng Y, Liu Z, Qiu J: Long non-coding RNA H19 increases bladder cancer metastasis by associating with EZH2 and inhibiting E-cadherin expression. Cancer Lett 2013, 333:213-221.

13. Gupta RA, Shah N, Wang KC, Kim J, Horlings HM, Wong DJ, Tsai MC, Hung T, Argani P, Rinn JL, Wang Y, Brzoska P, Kong B, Li R, West RB, van de Vijver MJ, Sukumar S, Chang HY: Long non-coding RNA HOTAIR reprograms chromatin state to promote cancer metastasis. Nature 2010, 464:1071-1076.

14. Hu P, Yang J, Hou Y, Zhang H, Zeng Z, Zhao L, Yu T, Tang X, Tu G, Cui X, Liu M: LncRNA expression signatures of twist-induced epithelial-tomesenchymal transition in MCF10A cells. Cell Signal 2014, 26:83-93.

15. $\mathrm{Li} \mathrm{CH}$, Chen $\mathrm{Y}$ : Targeting long non-coding RNAs in cancers: progress and prospects. Int J Biochem Cell Biol 2013, 45:1895-1910.

16. Hassan O, Ahmad A, Sethi S, Sarkar FH: Recent updates on the role of microRNAs in prostate cancer. J Hematol Oncol 2012, 5:9.

17. Budhu A, Ji J, Wang XW: The clinical potential of microRNAs. J Hematol Oncol 2010, 3:37.

18. Musumeci M, Coppola V, Addario A, Patrizii M, Maugeri-Sacca M, Memeo L, Colarossi C, Francescangeli F, Biffoni M, Collura D, Giacobbe A, D'Urso L, Falchi M, Venneri MA, Muto G, De Maria R, Bonci D: Control of tumor and microenvironment cross-talk by miR-15a and miR-16 in prostate cancer. Oncogene 2011, 30:4231-4242.

19. Tan S, Li R, Ding K, Lobie PE, Zhu T: miR-198 inhibits migration and invasion of hepatocellular carcinoma cells by targeting the HGF/c-MET pathway. FEBS Lett 2011, 585:2229-2234.

20. Zhao X, Dou W, He L, Liang S, Tie J, Liu C, Li T, Lu Y, Mo P, Shi Y, Wu K, Nie Y, Fan D: MicroRNA-7 functions as an anti-metastatic microRNA in gastric cancer by targeting insulin-like growth factor-1 receptor. Oncogene 2013, 32:1363-1372

21. Guttilla IK, Adams BD, White BA: ERalpha, microRNAs, and the epithelial-mesenchymal transition in breast cancer. Trends Endocrinol Metab 2012, 23:73-82

22. Du R, Sun W, Xia L, Zhao A, Yu Y, Zhao L, Wang H, Huang C, Sun S: Hypoxia-induced down-regulation of microRNA-34a promotes EMT by targeting the Notch signaling pathway in tubular epithelial cells. PLoS One 2012, 7:e30771.

23. Brabletz S, Bajdak K, Meidhof S, Burk U, Niedermann G, Firat E, Wellner U, Dimmler A, Faller G, Schubert J, Brabletz T: The ZEB1/miR-200 feedback loop controls Notch signalling in cancer cells. EMBO J 2011, 30:770-782

24. Saydam $O$, Shen $Y$, Wurdinger $T$, Senol O, Boke $E$, James MF, Tannous BA, Stemmer-Rachamimov AO, Yi M, Stephens RM, Fraefel C, Gusella JF, Krichevsky AM, Breakefield XO: Downregulated microRNA-200a in meningiomas promotes tumor growth by reducing E-cadherin and activating the Wnt/beta-catenin signaling pathway. Mol Cell Biol 2009, 29:5923-5940

25. Gill BJ, Gibbons DL, Roudsari LC, Saik JE, Rizvi ZH, Roybal JD, Kurie JM, West JL: A synthetic matrix with independently tunable biochemistry and mechanical properties to study epithelial morphogenesis and EMT in a lung adenocarcinoma model. Cancer Res 2012, 72:6013-6023.

26. Xu Q, Wang L, Li H, Han Q, Li J, Qu X, Huang S, Zhao RC: Mesenchymal stem cells play a potential role in regulating the establishment and maintenance of epithelial-mesenchymal transition in MCF7 human breast cancer cells by paracrine and induced autocrine TGF-beta. Int $J$ Oncol 2012, 41:959-968.

27. Xiong $M$, Jiang $L$, Zhou Y, Qiu W, Fang $L$, Tan R, Wen P, Yang J: The miR-200 family regulates TGF-beta1-induced renal tubular epithelial to mesenchymal transition through Smad pathway by targeting ZEB1 and ZEB2 expression. Am J Physiol Renal Physiol 2012, 302:F369-F379.

28. Turcatel G, Rubin N, El-Hashash A, Warburton D: MIR-99a and MIR-99b modulate TGF-beta induced epithelial to mesenchymal plasticity in normal murine mammary gland cells. PLoS One 2012, 7:e31032.

29. Su A, He S, Tian B, Hu W, Zhang Z: MicroRNA-221 mediates the effects of PDGF-BB on migration, proliferation, and the epithelial-mesenchymal transition in pancreatic cancer cells. PLoS One 2013, 8:e71309. 
30. Hong JP, Li XM, Li MX, Zheng FL: VEGF suppresses epithelial-mesenchymal transition by inhibiting the expression of Smad3 and miR192, a Smad3-dependent microRNA. Int J Mol Med 2013, 31:1436-1442.

31. Wang B, Herman-Edelstein M, Koh P, Burns W, Jandeleit-Dahm K, Watson A, Saleem M, Goodall GJ, Twigg SM, Cooper ME, Kanthatidis P: E-cadherin expression is regulated by miR-192/215 by a mechanism that is independent of the profibrotic effects of transforming growth factor-beta. Diabetes 2010, 59:1794-1802.

32. Zhang $Z$, Liu ZB, Ren WM, Ye XG, Zhang YY: The miR-200 family regulates the epithelial-mesenchymal transition induced by EGF/EGFR in anaplastic thyroid cancer cells. Int J Mol Med 2012, 30:856-862.

33. Lei $C$, Wang $Y$, Huang $Y$, Yu H, Wu L, Huang L: Up-regulated miR155 reverses the epithelial-mesenchymal transition induced by EGF and increases chemo-sensitivity to cisplatin in human Caski cervical cancer cells. PLoS One 2012, 7:e52310.

34. Mongroo PS, Rustgi AK: The role of the miR-200 family in epithelial-mesenchymal transition. Cancer Biol Ther 2010, 10:219-222

35. Gregory PA, Bert AG, Paterson EL, Barry SC, Tsykin A, Farshid G, Vadas MA, Khew-Goodall Y, Goodall GJ: The miR-200 family and miR-205 regulate epithelial to mesenchymal transition by targeting ZEB1 and SIP1. Nat Cell Biol 2008, 10:593-601.

36. Burk U, Schubert J, Wellner U, Schmalhofer O, Vincan E, Spaderna S, Brabletz T: A reciprocal repression between ZEB1 and members of the miR-200 family promotes EMT and invasion in cancer cells. EMBO Rep 2008, 9:582-589.

37. Wellner U, Schubert J, Burk UC, Schmalhofer O, Zhu F, Sonntag A, Waldvogel B, Vannier C, Darling D, zur Hausen A, Brunton VG, Morton J, Sansom O, Schuler J, Stemmler MP, Herzberger C, Hopt U, Keck T, Brabletz S, Brabletz T, Darling D, zur Hausen A, Brunton VG, Morton J, Sansom O, Schuler J, Stemmler MP, Herzberger C, Hopt U, Keck T, Brabletz S, Brabletz T: The EMT-activator ZEB1 promotes tumorigenicity by repressing stemness-inhibiting microRNAs. Nat Cell Biol 2009, 11:1487-1495.

38. Bracken CP, Gregory PA, Kolesnikoff N, Bert AG, Wang J, Shannon MF, Goodall GJ: A double-negative feedback loop between ZEB1-SIP1 and the microRNA-200 family regulates epithelial-mesenchymal transition. Cancer Res 2008, 68:7846-7854.

39. Mizuguchi $Y$, Specht S, Lunz JG 3rd, Isse K, Corbitt N, Takizawa T, Demetris AJ: Cooperation of p300 and PCAF in the control of microRNA 200c/141 transcription and epithelial characteristics. PLOS One 2012, 7:e32449.

40. Ahn SM, Cha JY, Kim J, Kim D, Trang HT, Kim YM, Cho YH, Park D, Hong S: Smad3 regulates E-cadherin via miRNA-200 pathway. Oncogene 2012, 31:3051-3059.

41. Chang $\mathrm{CJ}$, Chao CH, Xia W, Yang JY, Xiong Y, Li CW, Yu WH, Rehman SK, Hsu JL, Lee HH, Liu M, Chen CT, Yu D, Hung MC: p53 regulates epithelial-mesenchymal transition and stem cell properties through modulating miRNAs. Nat Cell Biol 2011, 13:317-323.

42. Schubert J, Brabletz T: p53 Spreads out further: suppression of EMT and stemness by activating miR-200c expression. Cell Res 2011, 21:705-707.

43. Fu J, Rodova M, Nanta R, Meeker D, van Veldhuizen PJ, Srivastava RK, Shankar S: NPV-LDE-225 (Erismodegib) inhibits epithelial mesenchymal transition and self-renewal of glioblastoma initiating cells by regulating miR-21, miR-128, and miR-200. Neuro Oncol 2013, 15:691-706.

44. Guo L, Chen C, Shi M, Wang F, Chen X, Diao D, Hu M, Yu M, Qian L, Guo N: Stat3-coordinated Lin-28-let-7-HMGA2 and miR-200-ZEB1 circuits initiate and maintain oncostatin M-driven epithelial-mesenchymal transition. Oncogene 2013, 32:5272-5282.

45. Kong D, Li Y, Wang Z, Banerjee S, Ahmad A, Kim HR, Sarkar FH: miR-200 regulates PDGF-D-mediated epithelial-mesenchymal transition, adhesion, and invasion of prostate cancer cells. Stem Cells 2009, 27:1712-1721.

46. Bao B, Wang Z, Ali S, Kong D, Li Y, Ahmad A, Banerjee S, Azmi AS, Miele L, Sarkar FH: Notch-1 induces epithelial-mesenchymal transition consistent with cancer stem cell phenotype in pancreatic cancer cells. Cancer Lett 2011, 307:26-36.

47. Sureban SM, May R, Qu D, Weygant N, Chandrakesan P, Ali N, Lightfoot SA Pantazis P, Rao CV, Postier RG, Houchen CW: DCLK1 Regulates Pluripotency and Angiogenic Factors via microRNA-Dependent Mechanisms in Pancreatic Cancer. PLoS One 2013, 8:e73940.

48. Grassian AR, Lin F, Barrett R, Liu Y, Jiang W, Korpal M, Astley H, Gitterman D, Henley $T$, Howes R, Levell J, Korn JM, Pagliarini R: Isocitrate dehydrogenase (IDH) mutations promote a reversible ZEB1/microRNA (miR)-200dependent epithelial-mesenchymal transition (EMT). J Biol Chem 2012, 287:42180-42194.
49. Martello G, Rosato A, Ferrari F, Manfrin A, Cordenonsi M, Dupont S, Enzo E, Guzzardo V, Rondina M, Spruce T, Parenti AR, Daidone MG, Bicciato S, Piccolo S: A MicroRNA targeting dicer for metastasis control. Cell 2010, 141:1195-1207.

50. Li BL, Lu C, Lu W, Yang TT, Qu J, Hong X, Wan XP: miR-130b is an EMT-related microRNA that targets DICER1 for aggression in endometrial cancer. Med Oncol 2013, 30:484.

51. Parker BC, Zhang W: Fusion genes in solid tumors: an emerging target for cancer diagnosis and treatment. Chin J Cancer 2013, 32:594-603.

52. Yoshimoto M, Joshua AM, Chilton-Macneill S, Bayani J, Selvarajah S, Evans AJ, Zielenska M, Squire JA: Three-color FISH analysis of TMPRSS2/ERG fusions in prostate cancer indicates that genomic microdeletion of chromosome 21 is associated with rearrangement. Neoplasia 2006, 8:465-469.

53. Leshem O, Madar S, Kogan-Sakin I, Kamer I, Goldstein I, Brosh R, Cohen Y, Jacob-Hirsch J, Ehrlich M, Ben-Sasson S, Goldfinger N, Loewenthal R, Gazit E, Rotter V, Berger R: TMPRSS2/ERG promotes epithelial to mesenchymal transition through the ZEB1/ZEB2 axis in a prostate cancer model. PLoS One 2011, 6:e21650

54. Hur K, Toiyama Y, Takahashi M, Balaguer F, Nagasaka T, Koike J, Hemmi H, Koi M, Boland CR, Goel A: MicroRNA-200c modulates epithelial-tomesenchymal transition (EMT) in human colorectal cancer metastasis. Gut 2013, 62:1315-1326.

55. Neves R, Scheel C, Weinhold S, Honisch E, Iwaniuk KM, Trompeter HI, Niederacher D, Wernet $P$, Santourlidis S, Uhrberg M: Role of DNA methylation in miR-200c/141 cluster silencing in invasive breast cancer cells. BMC Res Notes 2010, 3:219.

56. Wiklund ED, Bramsen JB, Hulf T, Dyrskjot L, Ramanathan R, Hansen TB, Villadsen SB, Gao S, Ostenfeld MS, Borre M, Peter ME, Orntoft TF, Kjems J, Clark SJ: Coordinated epigenetic repression of the miR-200 family and miR-205 in invasive bladder cancer. Int J Cancer 2011, 128:1327-1334.

57. Vrba L, Jensen TJ, Garbe JC, Heimark RL, Cress AE, Dickinson S, Stampfer MR, Futscher BW: Role for DNA methylation in the regulation of miR-200c and miR-141 expression in normal and cancer cells. PLoS One 2010, 5:e8697.

58. Wang Z, Zhao Y, Smith E, Goodall GJ, Drew PA, Brabletz T, Yang C: Reversal and prevention of arsenic-induced human bronchial epithelial cell malignant transformation by microRNA-200b. Toxicol Sci 2011, 121:110-122.

59. Dong P, Karaayvaz M, Jia N, Kaneuchi M, Hamada J, Watari H, Sudo S, Ju J, Sakuragi N: Mutant p53 gain-of-function induces epithelial-mesenchymal transition through modulation of the miR-130b-ZEB1 axis. Oncogene 2013, 32:3286-3295

60. Yokobori T, Suzuki S, Tanaka N, Inose T, Sohda M, Sano A, Sakai M, Nakajima M, Miyazaki T, Kato H, Kuwano H: MiR-150 is associated with poor prognosis in esophageal squamous cell carcinoma via targeting the EMT inducer ZEB1. Cancer Sci 2013, 104:48-54.

61. Harazono Y, Muramatsu T, Endo H, Uzawa N, Kawano T, Harada K, Inazawa J, Kozaki k: miR-655 Is an EMT-suppressive MicroRNA targeting ZEB1 and TGFBR2. PLoS One 2013, 8:e62757.

62. Lee JY, Park MK, Park JH, Lee HJ, Shin DH, Kang Y, Lee CH, Kong G: Loss of the polycomb protein Mel-18 enhances the epithelial-mesenchymal transition by ZEB1 and ZEB2 expression through the downregulation of miR-205 in breast cancer. Oncogene 2013. doi: 10.1038/onc.2013.53. [Epub ahead of print].

63. Tucci P, Agostini M, Grespi F, Markert EK, Terrinoni A, Vousden KH, Muller PA, Dotsch V, Kehrloesser S, Sayan BS, Giaccone G, Lowe SW, Takahashi N, Vandenabeele P, Knight RA, Levine AJ, Melino G: Loss of p63 and its microRNA-205 target results in enhanced cell migration and metastasis in prostate cancer. Proc Natl Acad Sci U S A 2012, 109:15312-15317.

64. Xu Q, Sun Q, Zhang J, Yu J, Chen W, Zhang Z: Downregulation of miR-153 contributes to epithelial-mesenchymal transition and tumor metastasis in human epithelial cancer. Carcinogenesis 2013, 34:539-549.

65. Kim NH, Kim HS, Li XY, Lee I, Choi HS, Kang SE, Cha SY, Ryu JK, Yoon D, Fearon ER, Rowe RG, Lee S, Maher CA, Weiss SJ, Yook Jl: A p53/miRNA-34 axis regulates Snail1-dependent cancer cell epithelial-mesenchymal transition. J Cell Biol 2011, 195:417-433.

66. Brabletz T: MiR-34 and SNAIL: another double-negative feedback loop controlling cellular plasticity/EMT governed by p53. Cell Cycle 2012, 11:215-216

67. Cha YH, Kim NH, Park C, Lee I, Kim HS, Yook Jl: MiRNA-34 intrinsically links p53 tumor suppressor and Wnt signaling. Cell Cycle 2012, 11:1273-1281.

68. Moes M, le Bechec A, Crespo I, Laurini C, Halavatyi A, Vetter G, Del Sol A, Friederich E: A novel network integrating a miRNA-203/SNAI1 feedback loop which regulates epithelial to mesenchymal transition. PLoS One 2012, 7:e35440. 
69. Qu Y, Li WC, Hellem MR, Rostad K, Popa M, McCormack E, Oyan AM, Kalland KH, Ke XS: MiR-182 and miR-203 induce mesenchymal to epithelial transition and self-sufficiency of growth signals via repressing SNAI2 in prostate cells. Int J Cancer 2013, 133:544-555.

70. Ding X, Park SI, MCCauley LK, Wang CY: Signaling between transforming growth factor beta (TGF-beta) and transcription factor SNAI2 represses expression of microRNA miR-203 to promote epithelial-mesenchymal transition and tumor metastasis. J Biol Chem 2013, 288:10241-10253.

71. Liu YN, Yin JJ, Abou-Kheir W, Hynes PG, Casey OM, Fang L, Yi M, Stephens RM, Seng V, Sheppard-Tillman H, Martin P, Kelly K: MiR-1 and miR-200 inhibit EMT via Slug-dependent and tumorigenesis via Slug-independent mechanisms. Oncogene 2013, 32:296-306.

72. Yang D, Sun Y, Hu L, Zheng H, Ji P, Pecot CV, Zhao Y, Reynold S, Cheng H, Rupaimoole R, Cogdell D, Nykter M, Broaddus R, Rodriguez-Aguayo C, Lopez-Berestein G, Liu J, Shmulevich I, Sood AK, Chen K, Zhang W: Integrated analyses identify a master microRNA regulatory network for the mesenchymal subtype in serous ovarian cancer. Cancer Cell 2013, 23:186-199.

73. Kumarswamy R, Mudduluru G, Ceppi P, Muppala S, Kozlowski M, Niklinski J, Papotti M, Allgayer H: MicroRNA-30a inhibits epithelial-to-mesenchymal transition by targeting Snai1 and is downregulated in non-small cell lung cancer. Int J Cancer 2012, 130:2044-2053.

74. Ru P, Steele R, Newhall P, Phillips NJ, Toth K, Ray RB: miRNA-29b suppresses prostate cancer metastasis by regulating epithelialmesenchymal transition signaling. Mol Cancer Ther 2012, 11:1166-1173.

75. Chang CJ, Hsu CC, Chang CH, Tsai LL, Chang YC, Lu SW, Yu CH, Huang HS, Wang JJ, Tsai CH, Chou MY, Yu CC, Hu FW: Let-7d functions as novel regulator of epithelial-mesenchymal transition and chemoresistant property in oral cancer. Oncol Rep 2011, 26:1003-1010.

76. Li B, Han Q, Zhu Y, Yu Y, Wang J, Jiang X: Down-regulation of miR-214 contributes to intrahepatic cholangiocarcinoma metastasis by targeting Twist. FEBS J 2012, 279:2393-2398.

77. Nairismagi ML, Vislovukh A, Meng Q, Kratassiouk G, Beldiman C, Petretich M, Groisman R, Fuchtbauer EM, Harel-Bellan A, Groisman I: Translational control of TWIST1 expression in MCF-10A cell lines recapitulating breast cancer progression. Oncogene 2012, 31:4960-4966.

78. Hernandez JM, Elahi A, Clark CW, Wang J, Humphries LA, Centeno B, Bloom G, Fuchs BC, Yeatman T, Shibata D: miR-675 Mediates Downregulation of Twist 1 and Rb in AFP-Secreting Hepatocellular Carcinoma. Ann Surg Oncol 2013(Suppl 3):S625-635.

79. Yang F, Sun L, Li Q, Han X, Lei L, Zhang H, Shang Y: SET8 promotes epithelial-mesenchymal transition and confers TWIST dual transcriptional activities. EMBO J 2012, 31:110-123.

80. Song F, Zheng H, Liu B, Wei S, Dai H, Zhang L, Calin GA, Hao X, Wei Q, Zhang W, Chen K: An miR-502-binding site single-nucleotide polymorphism in the 3'-untranslated region of the SET8 gene is associated with early age of breast cancer onset. Clin Cancer Res 2009, 15:6292-6300.

81. Ma L, Young J, Prabhala H, Pan E, Mestdagh P, Muth D, Teruya-Feldstein J, Reinhardt F, Onder TT, Valastyan S, Westermann F, Speleman F, Vandesompele J, Weinberg RA: miR-9, a MYC/MYCN-activated microRNA, regulates E-cadherin and cancer metastasis. Nat Cell Biol 2010, 12:247-256.

82. Cao M, Seike M, Soeno C, Mizutani H, Kitamura K, Minegishi Y, Noro R, Yoshimura A, Cai L, Gemma A: MiR-23a regulates TGF-beta-induced epithelial-mesenchymal transition by targeting E-cadherin in lung cancer cells. Int J Oncol 2012, 41:869-875.

83. Khew-Goodall Y, Goodall GJ: Myc-modulated miR-9 makes more metastases. Nat Cell Biol 2010, 12:209-211.

84. Lu MH, Huang CC, Pan MR, Chen HH, Hung WC: Prospero homeobox promotes epithelial-mesenchymal transition in colon cancer cells by inhibiting E-cadherin via miR-9. Clin Cancer Res 2012, 18:6416-6425.

85. Sun Z, Han Q, Zhou N, Wang S, Lu S, Bai C, Zhao RC: MicroRNA-9 enhances migration and invasion through KLF17 in hepatocellular carcinoma. Mol Oncol 2013, 7:884-894

86. Arora H, Qureshi R, Park WY: miR-506 regulates epithelial mesenchymal transition in breast cancer cell lines. PLoS One 2013, 8:e64273.

87. Cheng CW, Wang HW, Chang CW, Chu HW, Chen CY, Yu JC, Chao Jl, Liu HF, Ding SL, Shen CY: MicroRNA-30a inhibits cell migration and invasion by downregulating vimentin expression and is a potential prognostic marker in breast cancer. Breast Cancer Res Treat 2012, 134:1081-1093.

88. Shan SW, Fang L, Shatseva T, Rutnam ZJ, Yang X, Du W, Lu WY, Xuan JW, Deng Z, Yang BB: Mature miR-17-5p and passenger miR-17-3p induce hepatocellular carcinoma by targeting PTEN, GaINT7 and vimentin in different signal pathways. J Cell Sci 2013, 126:1517-1530

89. Furuta M, Kozaki Kl, Tanaka S, Arii S, Imoto I, Inazawa J: miR-124 and miR-203 are epigenetically silenced tumor-suppressive microRNAs in hepatocellular carcinoma. Carcinogenesis 2010, 31:766-776

90. Yamasaki T, Seki N, Yamada Y, Yoshino H, Hidaka H, Chiyomaru T, Nohata N, Kinoshita T, Nakagawa M, Enokida H: Tumor suppressive microRNA138 contributes to cell migration and invasion through its targeting of vimentin in renal cell carcinoma. Int J Oncol 2012, 41:805-817.

91. Liu X, Wang C, Chen Z, Jin Y, Wang Y, Kolokythas A, Dai Y, Zhao X: MicroRNA-138 suppresses epithelial-mesenchymal transition in squamous cell carcinoma cell lines. Biochem J 2011, 440:23-31.

92. Tang O, Chen XM, Shen S, Hahn M, Pollock CA: MiRNA-200b represses transforming growth factor-beta1-induced EMT and fibronectin expression in kidney proximal tubular cells. Am J Physiol Renal Physiol 2013, 304:F1266-1273.

93. Shan SW, Lee DY, Deng Z, Shatseva T, Jeyapalan Z, Du WW, Zhang Y, Xuan JW, Yee SP, Siragam V, Yang BB: MicroRNA MiR-17 retards tissue growth and represses fibronectin expression. Nat Cell Biol 2009, 11:1031-1038.

94. Chai S, Ma S: Clinical implications of microRNAs in liver cancer stem cells. Chin J Cancer 2013, 32:419-426.

95. Krutzfeldt J, Rajewsky N, Braich R, Rajeev KG, Tuschl T, Manoharan M, Stoffel M: Silencing of microRNAs in vivo with 'antagomirs'. Nature 2005, 438:685-689.

96. Rupaimoole R, Han HD, Lopez-Berestein G, Sood AK: MicroRNA therapeutics: principles, expectations, and challenges. Chin J Cancer 2011, 30:368-370.

97. Song F, Yang D, Liu B, Guo Y, Zheng H, Li L, Wang T, Yu J, Zhao Y, Niu R, Liang $H$, Winkler $H$, Zhang W, Hao $X$, Chen $K$ : Integrated microRNA network analyses identify a poor-prognosis subtype of gastric cancer characterized by the miR-200 family. Clin Cancer Res 2013, 20:878-889.

98. Pecot CV, Rupaimoole R, Yang D, Akbani R, Ivan C, Lu C, Wu S, Han HD, Shah MY, Rodriguez-Aguayo C, Bottsford-Miller J, Liu Y, Kim SB, Unruh A, Gonzalez-Villasana V, Huang L, Zand B, Moreno-Smith M, Mangala LS, Taylor M, Dalton HJ, Sehgal V, Wen Y, Kang Y, Baggerly KA, Lee JS, Ram PT, Ravoori MK, Kundra $V$, Zhang $X$, et al: Tumour angiogenesis regulation by the miR-200 family. Nat Commun 2013, 4:2427.

99. Papadimitriou E, Vasilaki E, Vorvis C, Iliopoulos D, Moustakas A, Kardassis D, Stournaras C: Differential regulation of the two RhoA-specific GEF isoforms Net1/Net1A by TGF-beta and miR-24: role in epithelial-to-mesenchymal transition. Oncogene 2012, 31:2862-2875.

100. Gebeshuber CA, Zatloukal K, Martinez J: miR-29a suppresses tristetraprolin, which is a regulator of epithelial polarity and metastasis. EMBO Rep 2009, 10:400-405.

101. Smith AL, Iwanaga R, Drasin DJ, Micalizzi DS, Vartuli RL, Tan AC, Ford HL: The miR-106b-25 cluster targets Smad7, activates TGF-beta signaling, and induces EMT and tumor initiating cell characteristics downstream of Six1 in human breast cancer. Oncogene 2012, 31:5162-5171.

102. Stinson S, Lackner MR, Adai AT, Yu N, Kim HJ, O'Brien C, Spokerke J, Jhunjhunwala S, Boyd Z, Januario T, Newman RJ, Yue P, Bourgon R, Modrusan Z, Stern HM, Warming S, de Sauvage FJ, Amler L, Yeh RF, Dornan D: TRPS1 targeting by miR-221/222 promotes the epithelial-to-mesenchymal transition in breast cancer. Sci Signal 2011, 4:ra41.

103. Cai J, Guan H, Fang L, Yang Y, Zhu X, Yuan J, Wu J, Li M: MicroRNA-374a activates $\mathrm{Wnt} /$ beta-catenin signaling to promote breast cancer metastasis. J Clin Invest 2013, 123:566-579.

104. Ward A, Balwierz A, Zhang JD, Kublbeck M, Pawitan Y, Hielscher T, Wiemann S, Sahin O: Re-expression of microRNA-375 reverses both tamoxifen resistance and accompanying EMT-like properties in breast cancer. Oncogene 2013, 32:1173-1182.

105. Li QQ, Chen ZQ, Cao XX, Xu JD, Xu JW, Chen YY, Wang WJ, Chen Q, Tang F, Liu XP, Xu ZD: Involvement of NF-kappaB/miR-448 regulatory feedback loop in chemotherapy-induced epithelial-mesenchymal transition of breast cancer cells. Cell Death Differ 2011, 18:16-25.

106. Vetter G, Saumet A, Moes M, Vallar L, le Bechec A, Laurini C, Sabbah M Arar K, Theillet C, Lecellier CH, Friederich E: miR-661 expression in SNAl1-induced epithelial to mesenchymal transition contributes to breast cancer cell invasion by targeting Nectin-1 and StarD10 messengers. Oncogene 2010, 29:4436-4448.

107. Zhang Z, Liu S, Shi R, Zhao G: miR-27 promotes human gastric cancer cell metastasis by inducing epithelial-to-mesenchymal transition. Cancer Genet 2011, 204:486-491. 
108. Hamada S, Satoh K, Miura S, Hirota M, Kanno A, Masamune A, Kikuta K, Kume K, Unno J, Egawa S, Motoi F, Unno M, Shimosegawa T: miR-197 induces epithelial-mesenchymal transition in pancreatic cancer cells by targeting p120 catenin. J Cell Physiol 2013, 228:1255-1263.

109. Bao L, Yan Y, Xu C, Ji W, Shen S, Xu G, Zeng Y, Sun B, Qian H, Chen L, Wu M, Su C, Chen J: MicroRNA-21 suppresses PTEN and hSulf-1 expression and promotes hepatocellular carcinoma progression through AKT/ERK pathways. Cancer Lett 2013, 337:226-236.

110. Dong P, Kaneuchi M, Watari H, Hamada J, Sudo S, Ju J, Sakuragi N: MicroRNA-194 inhibits epithelial to mesenchymal transition of endometrial cancer cells by targeting oncogene BMI-1. Mol Cancer 2011 10:99.

111. Zhang LY, Liu M, Li X, Tang H: miR-490-3p modulates cell growth and epithelial to mesenchymal transition of hepatocellular carcinoma cells by targeting endoplasmic reticulum-Golgi intermediate compartment protein 3 (ERGIC3). J Biol Chem 2013, 288:4035-4047.

112. Zhou Y, Li Y, Ye J, Jiang R, Yan H, Yang X, Liu Q, Zhang J: MicroRNA-491 is involved in metastasis of hepatocellular carcinoma by inhibitions of matrix metalloproteinase and epithelial to mesenchymal transition. Liver Int 2013, 33:1271-1280.

113. Tao $Z H$, Wan JL, Zeng $L Y$, Xie L, Sun $H C$, Qin $L X$, Wang $L$, Zhou J, Ren $Z G$, Li YX, Fan J, Wu WZ: miR-612 suppresses the invasive-metastatic cascade in hepatocellular carcinoma. J Exp Med 2013, 210:789-803.

114. Cui SY, Huang JY, Chen YT, Song HZ, Feng B, Huang GC, Wang R, Chen LB, De W: Let-7c governs the acquisition of chemo- or radioresistance and epithelial-to-mesenchymal transition phenotypes in docetaxel-resistant lung adenocarcinoma. Mol Cancer Res 2013, 11:699-713.

115. Xia H, Ooi LL, Hui KM: MicroRNA-216a/217-induced epithelialmesenchymal transition targets PTEN and SMAD7 to promote drug resistance and recurrence of liver cancer. Hepatology 2013, 58:629-641.

116. Qi J, Rice SJ, Salzberg AC, Runkle EA, Liao J, Zander DS, Mu D: MiR-365 regulates lung cancer and developmental gene thyroid transcription factor 1. Cell Cycle 2012, 11:177-186.

117. Luo C, Tetteh PW, Merz PR, Dickes E, Abukiwan A, Hotz-Wagenblatt A, Holland-Cunz S, Sinnberg T, Schittek B, Schadendorf D, Diederichs S, Eichmuller SB: miR-137 inhibits the invasion of melanoma cells through downregulation of multiple oncogenic target genes. J Invest Dermatol 2013, 133:768-775

118. Li J, Wang Y, Luo J, Fu Z, Ying J, Yu Y, Yu W: miR-134 inhibits epithelial to mesenchymal transition by targeting FOXM1 in non-small cell lung cancer cells. FEBS Lett 2012, 586:3761-3765.

119. Ke Y, Zhao W, Xiong J, Cao R: miR-149 inhibits Non-small-cell lung cancer cells EMT by targeting FOXM1. Biochem Res Int 2013, 2013:506731.

120. Chao A, Lin CY, Lee YS, Tsai CL, Wei PC, Hsueh S, Wu TI, Tsai CN, Wang CJ, Chao AS, Wang TH, Lai CH: Regulation of ovarian cancer progression by microRNA-187 through targeting Disabled homolog-2. Oncogene 2012, 31:764-775.

121. Hamada S, Satoh K, Fujibuchi W, Hirota M, Kanno A, Unno J, Masamune A, Kikuta K, Kume K, Shimosegawa T: MiR-126 acts as a tumor suppressor in pancreatic cancer cells via the regulation of ADAM9. Mol Cancer Res 2012, 10:3-10.

122. Cheng H, Zhang L, Cogdell DE, Zheng H, Schetter AJ, Nykter M, Harris CC, Chen K, Hamilton SR, Zhang W: Circulating plasma MiR-141 is a novel biomarker for metastatic colon cancer and predicts poor prognosis. PLOS One 2011, 6:e17745.

123. Ocana OH, Corcoles R, Fabra A, Moreno-Bueno G, Acloque H, Vega S, Barrallo-Gimeno A, Cano A, Nieto MA: Metastatic colonization requires the repression of the epithelial-mesenchymal transition inducer Prrx1. Cancer Cell 2012, 22:709-724.

124. Tsai JH, Donaher JL, Murphy DA, Chau S, Yang J: Spatiotemporal regulation of epithelial-mesenchymal transition is essential for squamous cell carcinoma metastasis. Cancer Cell 2012, 22:725-736.

doi:10.1186/1756-8722-7-19

Cite this article as: Guo et al: Post-transcriptional regulatory network of epithelial-to-mesenchymal and mesenchymal-to-epithelial transitions. Journal of Hematology \& Oncology 2014 7:19.

\section{Submit your next manuscript to BioMed Central and take full advantage of:}

- Convenient online submission

- Thorough peer review

- No space constraints or color figure charges

- Immediate publication on acceptance

- Inclusion in PubMed, CAS, Scopus and Google Scholar

- Research which is freely available for redistribution 